\title{
Extent and types of management consulting services to SMEs in Vojvodina ${ }^{4}$
}

\author{
Article history: \\ Received: 12. May 2013 \\ Sent for revision: 27. May 2013 \\ Received in revised form: 07 . July 2013 \\ Accepted: 08. July 2013 \\ Available online: 06. Novembre 2013
}

\begin{abstract}
This paper highlights the importance of management consulting for growth and development of SMEs. We have researched and analyzed the extent of use of management consulting (MC) services, separately in the micro, small and medium enterprises. In addition, we learn which types of $M C$ services are most commonly used by companies of different sizes. In the study was used the method of surveying by questionnaire with questions of closed and mixed type, in order to determine the possible existence of causal relation between size or age of SME on the one side, and volume of use of $M C$ services on the other side. It was observed that, with growth of the SMEs, comes the increase in volume of use, and sophistication of services used. Micro enterprises use fewer MC services, those with more general character, in the field of sales, state support projects, bussiness plans, etc., while small, especially medium enterprises, need more complex MC services, such as participation on exhibitions, finance, quality management systems, information systems and technologies, import-export, etc. The results may be useful both for small and medium enterprises, as well as for institutional and private providers of management consulting services.
\end{abstract}

Keywords: Entrepreneurs, small and medium enterprises, management consulting, growth and development of SMEs.

\footnotetext{
${ }^{1}$ University of Novi Sad, Faculty of Technical Sciences, dmadukic@gmail.com

2 University Union - Nikola Tesla, Belgrade, majstorovicaleksandar@gmail.com

${ }^{3}$ University Union, Faculty of Entrepreneurial Business, Belgrade, ajugoslav@yahoo.com

${ }^{4}$ This paper presents part of results of a research project 114-451-2477 entitled "Business Consulting in function of growth and development of small and medium-sized enterprises", financed by the Provincial Secretariat for Science and Technological Development APV.
} 
Dukić D. et al.: Extent and types of management consulting services to SMEs in...

\title{
Obim i vrste usluga menadžment konsaltinga u MSP u Vojvodini
}

\begin{abstract}
Apstrakt: $U$ radu se ističe značaj menadžment konsaltinga za rast $i$ razvoj MSP. Istražuje se $i$ analizira obim korišćenja menadžment konsalting (MK) usluga, zasebno u mikro, malim i srednjim preduzećima. Pored toga, dolazi se i do saznanja koje vrste MK usluga najčešće koriste preduzeća različitih veličina. $U$ istraživanju se koristi metod anketiranja, sa pitanjima zatvorenog $i$ mešovitog tipa, sa ciljem da se utvrdi eventualno postojanje kauzalne veze između veličine $i$ starosti malih $i$ srednjih preduzeća, $s$ jedne strane, $i$ obim korišćenja MK usluga, sa druge strane. Uočeno je da sa rastom preduzeća dolazi do povećanja obima korišćenja, ali i sofisticiranosti korišćenih usluga. Mikro preduzeća malo koriste MK usluge, i to one opštijeg karaktera, iz oblasti prodaje, projekata državne podrške, biznis planova, i sl., dok mala, a pogotovo srednja preduzeća, imaju potrebu za kompleksnijim MK uslugama, poput organizovanja učešća na sajmovima, finansija, sistema menadžmenta kvalitetom, informacionih sistema i tehnologija, uvoza-izvoza, itd. Dobijeni rezultati mogu biti korisni kako za sama mala i srednja preduzeća, tako i za institucionalne i privatne pružaoce menadžment konsalting usluga.
\end{abstract}

Ključne reči: Preduzetnici, mala i srednja preduzeća, menadžment konsalting, rast i razvoj MSP.

\section{Introduction}

Entrepreneurship is at the root of business, and the entrepreneur is an initiator and an innovator, who turns the idea in particular value on the market. With growth and development of a business, that is, the organization through which certain business activities are realized, management gains on the importance. Since larger and more developed organization requires structural and systematic managing, management knowledge and skills are becoming more and more important as the company grows and develops. Any organization will fail if there is no one to manage it. Not knowing how to manage is one of key reasons for failure on new entrepreneurial ventures and small and medium enterprises (Drucker, 2003).

This is not about separating management on two personalities, but observing the entrepreneur and manager within a certain phase of development in doing business and its primary interest, shown by certain priority goals. The role of an entrepreneur is, of course, more important in initial phases of the company's life cycle, while the manager's role is more important in the following phases. Therefore, for successful leading of the enterprise, it is necessary to achieve a symbiosis of leadership, entrepreneurial spirit and 
Dukić D. et al.: Extent and types of management consulting services to SMEs in...

managerial knowledge and skills. If he wants to succeed on the market, to grow and develop, the entrepreneur must own basic management knowledge and skills, while manager that is forced by market laws, must modify and innovate his traditional way of managing, and adopt elements of "entrepreneurial management" (Rajkov \& Sajfert, 1999).

Adizes (1994) points out that management does not mean leading the system from a stage where there is a problem and leading it to a stage where there are no problems, it means rising to the next problem level, to the next generation of the problem. This means that even professional managers, as do entrepreneurs, consantly face new, more complex problems compared to the previous or existing ones.

In modern business ambience, market competition forces enterprises to change faster, adapt and advance their business activities, which is why it is necessary to upgrade every segment of business to a higher level of competitiveness. It is obvious that entrepreneurs and small business owners require external help from individuals and organizations with a high degree of professional knowledge in a certain field of business. This kind of services is given to them by state and private consulting organizations, and independent consultants (Dukić \& Nikolić, 2010; Mughan, Lioyd-Reason \& Zimmermann, 2004).

Applebaum \& Hinds (1984) define management consultants as professionals that work with firm executives-managers, in order to solve specific business problems. In many science studies the meaning of consulting and training is pointed out (Storey, 2004; Christensen \& Klyver, 2006), as well as the meaning of adjusting and implementation of adequate managerial models, with pupose of developing SMEs (Naylor, Hawkins \& Wilson, 2000; McLarty, 2003; Dukić \& Milivojević, 2011). Projects of external consultation support enable entrepreneurs to gain explicit and implicit managerial knowledge that can be the basis for the development of sustainable competitive advantage (Crisman, \& McMullan, 2000). However, every form of consulting support must be as precisely created as possible, measured and directed, depending on the size and the development level of the enterprise.

Of course, this does not negate nor diminish the meaning and need for financial support to SME sector, or the meaning of removing obstacles and creating favorable business ambience for the development of these enterprises. Actually, only if all these factors, internal and external, micro and macro, financial and non-financial, are present in an optimal volume and mutually harmonized and balanced, they can give expected results.

In the world, understanding of business consulting, that is, management consulting (MC), has grown considerably at the end of the twentieth and in the beginning of this century. Empirical research has shown that most reasons for business consulting are connected with the need for new ideas and business 
Dukić D. et al.: Extent and types of management consulting services to SMEs in...

solutions, that is, professional and objective expertise (Gattiker \& Larwood, 1985). Apart from that, an important reason for using business consulting is also a desire to shorten the time needed for solving business problems (Hagedorn, 1982). At the same time, the understanding of business consulting potentials as a support for the growth and development of small business, also grew.

Since entrepreneurs and small and medium business owners are facing numerous and various problems, the consultants must be prepared to satisfy different needs of these clients. Since it is difficult to define problems only as financial, it is important for clients that they can require and get financial and other consulting services that are coordinated and supplemented with pieces of advice regarding different views on the problem that is being solved (Mihajlović, Paraušić \& Potrebić, 2006). In such circumstances, the consultant can be considered as a "one-stop shop" service for all necessary help (Kubr, 2002).

Recently, in our economy, the development of consulting activities has also been evident. In that regard, the engagement of the state, that is, the Agency for the development of small and medium-sized enterprises, is especially important, since it provides support to SMEs through the network of regional agencies, with the goal to enhance the founding and the work of small economy sector in the country (National Agency for Regional Development, 2011).

Accordingly, the motives for the existence and meaning of business consulting can be related to the role of the consultants themselves, because:

- Consultants can offer a broad knowledge and access to information;

- They have more experience than clients, in areas for which they provide consulting services;

- They can dedicate more time to research and problem analysis;

- Consultants are professionals (that is their principal, or one of the principle jobs);

- They are independent and make unbiased decisions easily;

- They have the ability to implement recommendations in practice. (Bower, 1982)

A great deal of practical experience shows that the forms of help needed by entrepreneurs and small business owners, are very different, and they depend on many factors, among which are the following:

- Education degree and business education of the entrepreneur;

- Personal skills and capabilities of the entrepreneur;

- Nature of business activity and characteristics of the economy branch;

- Size and age of the enterprise;

- Phase of the development cycle (initial phase, expansion...); 
Dukić D. et al.: Extent and types of management consulting services to SMEs in...

- Available entrepreneurial infrastructure in the area, and others.

Considering that the management consulting in Serbia is present in the sphere of running the business of small and medium-sized enterprises and entrepreneurs, the need for further analysis of its application and meaning for the growth and development of SMEs in our business ambience is evident.

The goal of this work is to explore and analyze the (non)existence of interdependent types of management consulting services and age, that is, the size of SME, and to dynamically see the change of requirements for different kinds of management consulting services in the context of the growth and development of the enterprise.

In that respect, there are three basic hypotheses in this paper which should be confirmed or refuted:

- The older small or medium enterprise get, i.e. the more time it spend in business, the greater awareness it achieves of the value and advantages of using MC services.

- Growing SME results in growing use of MC services.

- Larger SME uses more complex MC services.

In order to perceive corespondency between success and growth of SME on the on side, and use of MC services on the other side, i.e. to notice and emphasize the importance of specific types of $M C$ services for growth and development of SME, we analyzed micro, small and medium enterprises that have increased the number of employees in recent past, which is considered a success in existing conditions of recession.

\section{Methods and Materials}

In order to acquire a detailed insight into characteristics of business consulting for SMEs in our transitional circumstances, and its implications on the growth of small enterprises, this research was realized, through a survey questionnaire, in the second half of 2012 . The very aim of the research was to ascertain the scope and type of management consulting services, from the aspect of size and the age of micro, small or medium-sized enterprises that achieved certain growth rate in the previous period.

\subsection{Methodology}

Enterprises that achieve the growth - growing enterprises, through the growth rate of employment, income and added value stimulate the growth and development of the entire economy, which is why the state by its measures supports and encourages the growth of small and medium-sized enterprises. 
Dukić D. et al.: Extent and types of management consulting services to SMEs in...

The research of the problem and the challenges of growing enterprises show that support measures must be directed, from one hand, towards entrepreneurship and SMEs in general and from the other hand, towards the entrepreneurs and small enterprises that have high aspirations and growth potentials.

Measuring production growth can be performed in several different ways, which all depend on selected indicators such as, for example, total income growth, number of employees, market value of the enterprise, market share, value of goods or service brand, property value (assets) of the enterprise, etc. (Birch, 1981). In recession, operating expenses can be lowered by reducing the number of employees. Having that in mind, we can assume that those enterprises on the increase, which do not reduce the number of emoloyees, have undoubtedly achieved growth. On the other hand, it is known that in our economic ambience, part of business activities is placed in the so called "grey zone", which makes other indices of growth (growth of total income, growth of capital ...) relatively questionable. Therefore, increase in the number of employees in particular enterprise is taken as criteria of SME growth.

Most famous criteria of that type, also include Birch index - DaBeg, which can be applied to changes in the number of employees, added value or they combination. In this research, a relative growth of employment was used as a growth indicator, which enables the comparison of the growth of micro, small and medium-sized enterprises (Birch, 1987).

$$
D a B e g=\left(z_{t n}-z_{t n-5}\right) \times \frac{z_{t n}}{z_{t n-5}}
$$

$\boldsymbol{Z}=$ average number of employees in a given year $(\boldsymbol{t} \boldsymbol{n})$

In accordance with the modified "Europe's 500" criteria of the European commission, in for any enterprise to be included in the list of fast growing SMEs, it should, beside other (pre)conditions, increase the number of employees by at least $30 \%$ in the past five years and achieve an income growth of at least 30\% (EFER, 1996). Considering the actual economic crisis, which makes difficult, slows down or completely prevents the growth and development of a large number of entrepreneurs and small and medium-sized enterprises, growing micro, small and medium-sized enterprises that meet even somewhat lower criteria are in the focus of this research. Therefore, in this research, the following criterion was applied: DaBeg $\geq 10$.

Needless to say, according to the established criteria, growing enterprises that achieved satisfying growth of employees, also achieved growth in other areas, such as a growth of total income, market share, etc. 
Dukić $D$. et al.: Extent and types of management consulting services to SMEs in...

The method of questionnaire surveying with questions of closed and mixed type is used in this paper in accordance with initial hypotheses.. By analyzing information collected through the process of surveying, it was made possible to confirm or negate initial hypotheses of research, and thus to determine the existence of causal relation between size or age of SME on the one side, and volume of use of MC services on the other.

\subsection{Sample}

The sample of entrepreneurs and owners of micro, small or medium-sized enterprises consisted of 144 entrepreneurs or SME owners, for the same number of enterprises. That means that only one person was surveyed from each enterprise, store or agency, either the owner or one of the owners.

The research included only those enterprises that at the time of the research had from 1-150 employees, including the temporary staff.

During the division of special groups of enterprises by size, only the number of employees was taken into account, and based on that criteria, a group of micro enterprises with one to ten employees was singled out as a special,. The structure of surveyed enterprises according to the total number of permanently and temporarily hired employees is shown in the following table (Table 1).

Table 1. The structure of surveyed enterprises by number of employees

\begin{tabular}{|l|c|c|c|}
\hline \multicolumn{1}{|c|}{ Size } & $\begin{array}{c}\text { Number of } \\
\text { employees }\end{array}$ & $\begin{array}{c}\text { Number of enterprises (and } \\
\text { entrepreneurs) in the sample }\end{array}$ & $\begin{array}{c}\text { Share of sample } \\
(\%)\end{array}$ \\
\hline Micro & $1-10$ & 77 & 53,5 \\
\hline Small & $11-49$ & 46 & 31,9 \\
\hline Medium ${ }^{*}$ & $50-150$ & 21 & 14,6 \\
\hline \multicolumn{2}{|c|}{ Total: } & 144 & 100,0 \\
\hline
\end{tabular}

${ }^{\star}$ According to the statutory criteria, medium enterprises employing 50-250 people, but this study has included in this category of companies with 50-150 employees.

Source: Author

From the aspect of age of the enterprise in the sample, the structure was given in the following table (Table 2). 
Dukić D. et al.: Extent and types of management consulting services to SMEs in...

Table 2. Age of enterprises in the sample

\begin{tabular}{|l|c|c|c|}
\hline $\begin{array}{c}\text { Year of enterprise } \\
\text { founding }\end{array}$ & Age & $\begin{array}{c}\text { Number of enterprises } \\
\text { (and entrepreneurs) }\end{array}$ & Share of sample (\%) \\
\hline 2007. and later & $<5$ years & 42 & 29,2 \\
\hline 2002-2006. & $5-10$ years & 45 & 31,3 \\
\hline 1997-2001. & $10-15$ years & 27 & 18,7 \\
\hline Before 1996. & $>15$ years & 30 & 20,8 \\
\hline \multicolumn{2}{|c|}{ Total: } & 144 & 100,0 \\
\hline
\end{tabular}

Source: Author

Most activities which surveyed enterprises perform, in different areas of business:

Table 3. Predominant activity of surveyed enterprises

\begin{tabular}{|c|c|c|}
\hline Predominant activity & $\begin{array}{l}\text { Number of } \\
\text { enterprises }\end{array}$ & Share (\%) \\
\hline Wholesale - Retail & 37 & 25,7 \\
\hline Crafts and services & 23 & 16,0 \\
\hline Agricultural production and processing & 19 & 13,2 \\
\hline Industrial production & 17 & 11,8 \\
\hline Wholesale and export -import & 14 & 9,7 \\
\hline Construction & 12 & 8,3 \\
\hline Tourism & 7 & 4,9 \\
\hline IT & 6 & 4,2 \\
\hline Real estate & 4 & 2,8 \\
\hline Other & 5 & 3,4 \\
\hline Total: & 144 & 100,0 \\
\hline
\end{tabular}

Source: Author

The analysis of educational structure of surveyed owners/managers show that almost half of the owners/managers hold a university degree. In some cases there were more than one founder, but only one person was questioned, that is, surveyed, and only the data for that person was taken into account (Table 4). 
Dukić $D$. et al.: Extent and types of management consulting services to SMEs in...

Table 4. The level of education of surveyed entrepreneurs and SME owners

\begin{tabular}{|l|c|c|}
\hline \multicolumn{1}{|c|}{ Level of education } & Number & Share of sample (\%) \\
\hline Less than four-years school & 12 & 8,3 \\
\hline Four-year schools (High school) & 26 & 18,1 \\
\hline Higher (two or three-years) school (College) & 29 & 20,2 \\
\hline Faculty & 71 & 49,3 \\
\hline Master or PhD & 6 & 4,1 \\
\hline \multicolumn{1}{|c|}{ Total: } & 144 & 100,0 \\
\hline
\end{tabular}

Source: Author

\section{Results and Discussion}

Out of total 144 surveyed enterprises, satisfying growth according to the formula (1) was accomplished by 65 enterprises (45\%), out of which 43 enterprises also meet the second criteria for taking part in the analysis, that is, beside that they grew they also used management consulting services. These 43 enterprises represent $30 \%$ of the total sample, but also $2 / 3$ of those enterprises that achieved satisfying growth. From one side, this can be considered an especially high percentage, but it still shows the coincidence that small and medium-sized enterprises that use MC services manage to achieve business growth, or vice versa, that the growing SMEs understand the importance of management consulting services to a greater extent than those SMEs that do not grow.

\subsection{Analysis of using management consulting services from the aspect of age and size of growing SMEs}

The following table shows the distribution of such enterprises in the test sample, viewed from the aspect of enterprise's age (Table 5).

Table 5. Distribution by age of enterprises which grew and used MC services

\begin{tabular}{|c|c|c|c|c|}
\hline Age of enterprise & $\begin{array}{c}\text { Number } \\
\text { enterprises } \\
\text { in the } \\
\text { sample }\end{array}$ & $\begin{array}{c}\text { Achieve } \\
\text { growth and } \\
\text { use MC } \\
\text { services }\end{array}$ & $\begin{array}{c}\text { Share in the total } \\
\text { sample (of } 144 \\
\text { enterprises) }\end{array}$ & $\begin{array}{c}\text { Share in the } \\
\text { corresponding } \\
\text { group of } \\
\text { enterprises }\end{array}$ \\
\hline$<5$ years & 42 & 12 & $8,3 \%$ & $28,6 \%$ \\
\hline $5-10$ years & 45 & 15 & $10,4 \%$ & $33,3 \%$ \\
\hline $10-15$ years & 27 & 8 & $5,6 \%$ & $29,6 \%$ \\
\hline$>15$ years & 30 & 8 & $5,6 \%$ & $26,7 \%$ \\
\hline Total: & 144 & 43 & $29,9 \%$ & \\
\hline
\end{tabular}


Dukić D. et al.: Extent and types of management consulting services to SMEs in...

Source: Author

Based on the received results, the conclusion cannot be derived on the trend of growth or reduction of $\mathrm{MC}$ services use by growing enterprises, as they age. It is possible to conclude that those growing enterprises that are founded after 2002 show somewhat lager tendencies towards using management consulting services. External consulting support is not the only or basic reason for their growth, but it did contribute, directly or indirectly, to the growth of the enterprise.

Somewhat different situation arises when using of business consulting services is viewed from the aspect of SMEs size. The following table (Table 6), that is, the graph (Fig. 1), give an insight in the distribution according to the size of the enterprises that grew and used management consulting services.

Table 6. Distribution according to the size of enterprises that grew and used $M C$ services

\begin{tabular}{|c|c|c|c|c|}
\hline $\begin{array}{c}\text { Size of } \\
\text { enterprise }\end{array}$ & $\begin{array}{c}\text { Number } \\
\text { enterprises in } \\
\text { the sample }\end{array}$ & $\begin{array}{c}\text { Achieved growth } \\
\text { and used MC } \\
\text { services }\end{array}$ & $\begin{array}{c}\text { Share in the total } \\
\text { sample (of 144 } \\
\text { enterprises) }\end{array}$ & $\begin{array}{c}\text { Share in the } \\
\text { corresponding group } \\
\text { of enterprises }\end{array}$ \\
\hline Micro & 77 & 12 & $8,3 \%$ & $15,6 \%$ \\
\hline Small & 46 & 15 & $10,4 \%$ & $32,6 \%$ \\
\hline Medium & 21 & 16 & $11,2 \%$ & $76,2 \%$ \\
\hline Total: & 144 & 43 & $29,9 \%$ & \\
\hline
\end{tabular}

Source: Author

Figure 1. Size of the enterprises that grew and used MC services

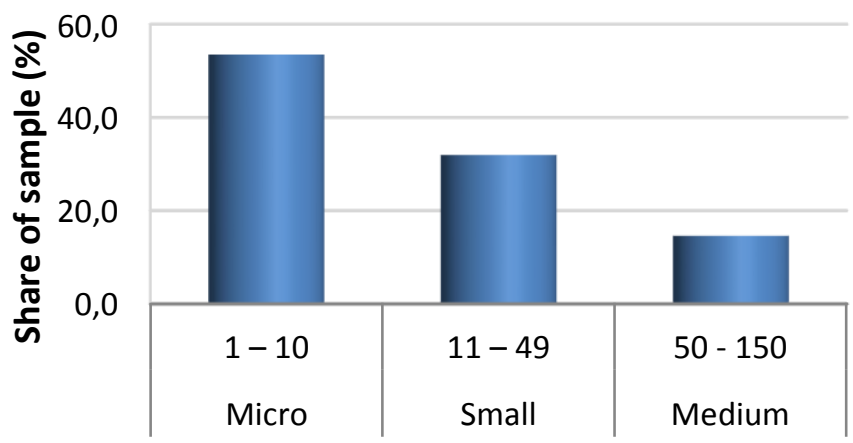

Size - number of employees

Source: Author 
Dukić D. et al.: Extent and types of management consulting services to SMEs in...

From the previous table, that is, graph, it can be concluded that along with the size of the enterprise, the share of growing enterprises that use MC service also arose. Growing enterprises with 50 or more employees stand out in particular, out of which more than two thirds use consulting services. They mainly have the capability to provide necessary funds. Their ownersmanagers can delegate part of their obligations to their associates, so that they can devote a part of their time to consulting projects and to personal (business) development and education. A part of the obligations related to consulting projects are usually partially or completely transferred to chosen associates.

Small and micro enterprises rarely considered external consulting services, regardless of the fact that they can benefit from the consulting service. This brings us to the fact that only every fifth micro, i.e., every third small enterprise uses MC services.

\subsection{Type of management consulting services used by SMEs}

The results of this research show that using management consulting (MC) services is not much different among growing small and medium-sized enterprises from different age groups, but it is different depending on the size of the enterprise. Therefore, it is interesting to see what types of $\mathrm{MC}$ services are mainly being used by micro, small and medium-sized enterprises, which is shown in the following table (Table 7). It is important to note here that all systems of classification of MC services have limitations. This is mainly because of integration of many services into a single project, or because of uniqueness of specific MC services (which makes it harder to classify in specific group of MC services).

Table 7. MC services used by growing SMEs

\begin{tabular}{|l|c|c|c|c|c|c|c|c|}
\hline \multirow{2}{*}{ Service } & \multicolumn{2}{|c|}{ Micro } & \multicolumn{2}{c|}{ Small } & \multicolumn{2}{c|}{ Medium } & \multicolumn{2}{c|}{ Total } \\
\cline { 2 - 11 } & $\begin{array}{c}\text { Number } \\
\text { of use }\end{array}$ & $\begin{array}{c}\text { Share } \\
\%\end{array}$ & $\begin{array}{c}\text { Number } \\
\text { of use }\end{array}$ & $\begin{array}{c}\text { Share } \\
\%\end{array}$ & $\begin{array}{c}\text { Number } \\
\text { of use }\end{array}$ & $\begin{array}{c}\text { Share } \\
\%\end{array}$ & $\begin{array}{c}\text { Number } \\
\text { of use }\end{array}$ & $\begin{array}{c}\text { Share } \\
\%\end{array}$ \\
\hline \hline Projects of state supporting to SME & 7 & 10,3 & 13 & 9,3 & 10 & 5,8 & 30 & 7,9 \\
\hline Business planning & 10 & 14,7 & 12 & 8,6 & 11 & 6,4 & 33 & 8,7 \\
\hline Training to apply for loans & 4 & 5,9 & 9 & 6,4 & 5 & 2,9 & 18 & 4,7 \\
\hline Import-Export & 1 & 1,5 & 6 & 4,3 & 12 & 7,0 & 19 & 5,0 \\
\hline Entrepreneurial start-up training & 5 & 7,4 & 4 & 2,9 & - & - & 9 & 2,4 \\
\hline Establishment and registr. of SME & 2 & 2,9 & 3 & 2,1 & - & - & 5 & 1,3 \\
\hline Marketing, sales and promotion & 9 & 13,2 & 8 & 5,7 & 8 & 4,7 & 25 & 6,6 \\
\hline Participation on exhibitions & 6 & 8,8 & 11 & 7,9 & 14 & 8,1 & 31 & 8,2 \\
\hline Development of sales skills & 5 & 7,4 & 7 & 5,0 & 10 & 5,8 & 22 & 5,8 \\
\hline \hline
\end{tabular}


Dukić D. et al.: Extent and types of management consulting services to SMEs in...

\begin{tabular}{|l|c|c|c|c|c|c|c|c|}
\hline \hline Improving competitiveness of SME & - & - & 2 & 1,4 & 3 & 1,7 & 5 & 1,3 \\
\hline Innovation and new technologies & 7 & 10,3 & 8 & 5,7 & 8 & 4,7 & 23 & 6,1 \\
\hline Training for female entrepren ship & 2 & 2,9 & - & - & - & - & 2 & 0,5 \\
\hline Finance, Accounting, Taxes & 6 & 8,8 & 8 & 5,7 & 14 & 8,1 & 28 & 7,4 \\
\hline Clusters & - & - & 2 & 1,4 & 4 & 2,3 & 6 & 1,6 \\
\hline Mentoring & 1 & 1,5 & 1 & 0,7 & - & - & 2 & 0,5 \\
\hline Quality Management Systems & - & - & 12 & 8,6 & 14 & 8,1 & 26 & 6,8 \\
\hline International and EU projects & - & - & 7 & 5,0 & 9 & 5,2 & 16 & 4,2 \\
\hline Inform. Systems and Technology & - & - & 8 & 5,7 & 14 & 8,1 & 22 & 5,8 \\
\hline Use of computers and Internet & 3 & 4,4 & 9 & 6,4 & 11 & 6,4 & 23 & 6,1 \\
\hline Project management & - & - & - & - & 4 & 2,3 & 4 & 1,1 \\
\hline Safety at work & - & - & 7 & 5,0 & 7 & 4,1 & 14 & 3,7 \\
\hline Human resources management & - & - & 2 & 1,4 & 5 & 2,9 & 7 & 1,8 \\
\hline Market research & - & - & 4 & 2,9 & 7 & 4,1 & 11 & 2,9 \\
\hline Strategy and business develop. & - & - & - & - & 2 & 1,2 & 2 & 0,5 \\
\hline \hline Total serv. used by the group: & 68 & 100 & 140 & 100 & 172 & 100 & 380 & 100 \\
\hline
\end{tabular}

Source: Author

One should be aware of the fact that not all enterprises used the same number of services, especially since some of them used only two types of services, and others ten or more. Table 7 shows the extent to which growing enterprises from each group used certain services and the share of total number of used MC services in that group of growing enterprises.

The results provide us with a wide range of management consulting services that were used by growing enterprises. We can see that growing micro enterprises used different types of MC services 68 times. However, it is impossible to make a short list of most commonly used services, and at the same time provide a summary for micro, small and medium-sized enterprises, since the order of commonly used services is different in the case of micro compared to small, or even these two groups compared to medium-sized enterprises. Therefore, a visual representation of the above table is more acceptable (Fig. 2). 
Dukić D. et al.: Extent and types of management consulting services to SMEs in...

Figure 2. MC services used by growing SMEs

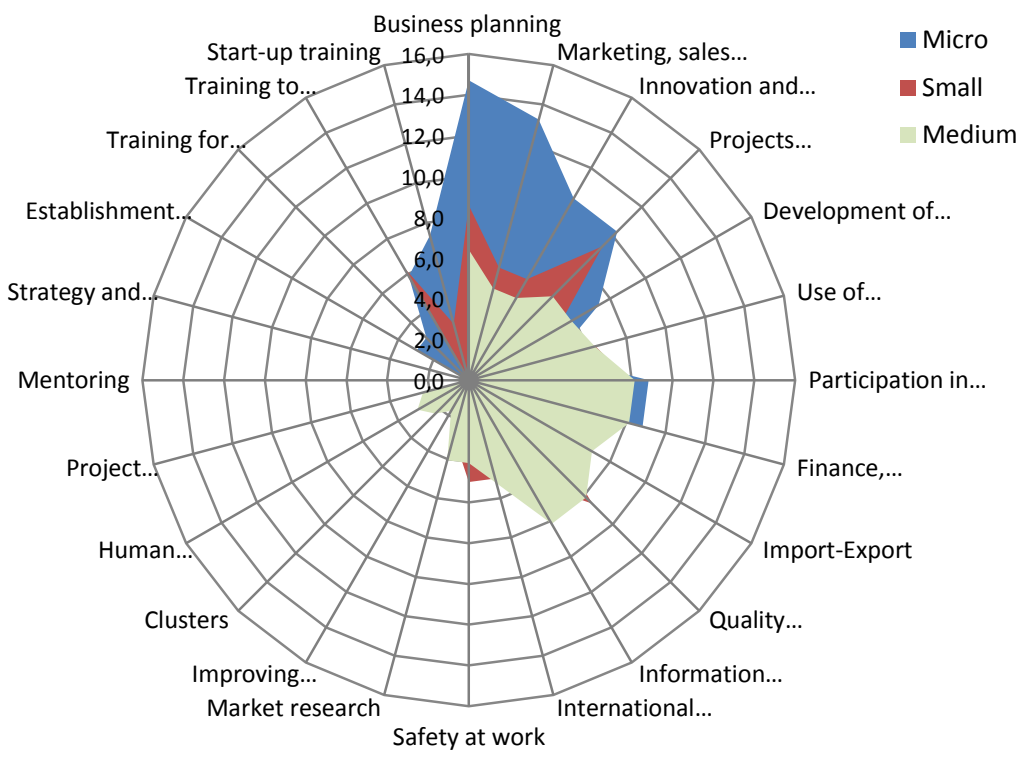

Source: Author

It is easy to conclude from the graph that as an enterprise grows, the focus shifts from start-up training, initial business plans and state support towards sophisticated and complex services, such as those from the field of system quality, information systems, import-export and professional market research.

Before we move to the analysis of every surveyed group of enterprises, it is interesting to see how many management consulting services were on average used by each enterprise in each group (Table 8 ).

Table 8. Average use of MC services by each enterprise in each group

\begin{tabular}{|l|c|c|c|c|}
\hline Size & $\begin{array}{c}\text { Number of } \\
\text { enterprises in } \\
\text { the sample }\end{array}$ & $\begin{array}{c}\text { Achieved growth } \\
\text { and used MC } \\
\text { services }\end{array}$ & $\begin{array}{c}\text { Number of used } \\
\text { consulting } \\
\text { services }\end{array}$ & $\begin{array}{c}\text { Average use by } \\
\text { each enterprise }\end{array}$ \\
\hline Micro & 77 & 12 & 68 & 5,7 \\
\hline Small & 46 & 15 & 140 & 9,3 \\
\hline Medium & 21 & 16 & 172 & 10,8 \\
\hline
\end{tabular}

Source: Author

It is evident that small and medium-sized enterprises use considerably more management consulting (MC) services comparing to micro enterprises. Still it 
Dukić D. et al.: Extent and types of management consulting services to SMEs in...

is not in full proportion with the size of the enterprise. Although medium-sized enterprises are at least five times larger than micro enterprises, they use only twice more MC services. However, if we were to observe the entire sample from this standpoint, it would be obvious that micro enterprises use in average $0,9 \mathrm{MC}$ services, and medium 8,2 MC services per an enterprise, which is nine times more.

The type of MC services that are mainly used in individual groups is shown in the following tables. When we aligne the services that are most frequently used in a descending order for each group individually, a clearer picture is obvious.

\section{Micro enterprises:}

For micro enterprises we receive a below-shown schedule, beginning with business planning, marketing and consulting in the domain of the project of the state support to SMEs (Table 9).

Table 9. MC services which are most commonly used by growing micro enterprises

\begin{tabular}{|l|c|c|}
\hline \multicolumn{1}{|c|}{ Service } & Number of use & Share $\%$ \\
\hline Business planning & 10 & 14,7 \\
\hline Marketing, sales and promotion & 9 & 13,2 \\
\hline Projects of state supporting to SMEs & 7 & 10,3 \\
\hline Innovation and new technologies & 7 & 10,3 \\
\hline Participation on exhibitions & 6 & 8,8 \\
\hline Finance, Accounting, Taxes & 6 & 8,8 \\
\hline Start-up training & 5 & 7,4 \\
\hline Development of sales skills & 5 & 7,4 \\
\hline Training to apply for loans & 4 & 5,9 \\
\hline Use of computers and Internet sites & 3 & 4,4 \\
\hline
\end{tabular}

Source: Author

\section{Small enterprises:}

The following table outlines the growing small business (Table 10). We can see that they, as well as micro enterprises, the most frequently used MC services in the domain of the projects of the state support to SMEs and business planning. However, services in the field of system quality hold the third place. It is obvious that small enterprises realize the meaning of quality systems, internet and information systems and technologies more than micro enterprises, while they are less interested in entrepreneurial stat-up training. 
Dukić D. et al.: Extent and types of management consulting services to SMEs in...

Table 10. MC services which are most commonly used by growing small enterprises

\begin{tabular}{|l|c|c|}
\hline \multicolumn{1}{|c|}{ Service } & Number of use & Share $\%$ \\
\hline Projects of state supporting to SMEs & 13 & 9,3 \\
\hline Business planning & 12 & 8,6 \\
\hline Quality Management Systems & 12 & 8,6 \\
\hline Participation on exhibitions & 11 & 7,9 \\
\hline Training to apply for loans & 9 & 6,4 \\
\hline Use of computers and Internet sites & 9 & 6,4 \\
\hline Marketing, sales and promotion & 8 & 5,7 \\
\hline Innovation and new technologies & 8 & 5,7 \\
\hline Finance, Accounting, Taxes & 8 & 5,7 \\
\hline Information systems and technologies & 8 & 5,7 \\
\hline
\end{tabular}

Source: Author

\section{Medium enterprises:}

The following table (Table 11) provides the overview of frequently used MC services by medium-sized enterprises. In these enterprises, the meaning of business organization and fairs is highly ranked. Equal attention is given to financial aspect, while quality systems remain important. Information systems and technologies have equal importance. Consulting in the area of importexport business has a very important importance in this group.

Table 11. MC services which are most commonly used by growing medium enterprises

\begin{tabular}{|l|c|c|}
\hline \multicolumn{1}{|c|}{ Service } & Number of use & Share $\%$ \\
\hline Participation on exhibitions & 14 & 8,1 \\
\hline Finance, Accounting, Taxes & 14 & 8,1 \\
\hline Quality Management Systems & 14 & 8,1 \\
\hline Information systems and technologies & 14 & 8,1 \\
\hline Import-Export & 12 & 7,0 \\
\hline Business planning & 11 & 6,4 \\
\hline Use of computers and Internet sites & 11 & 6,4 \\
\hline Projects of state supporting to SMEs & 10 & 5,8 \\
\hline Development of sales skills & 10 & 5,8 \\
\hline International and EU projects & 9 & 5,2 \\
\hline
\end{tabular}

Source: Author

It is obvious that these enterprises are more active and independent, they depend more on their own strengths, knowledge and skills. To a smaller extent they are dependent on state support, even though the importance of 
Dukić D. et al.: Extent and types of management consulting services to SMEs in...

that support is still present, and they are gradually directed towards international projects and jobs.

Detailed research like this one, which are dealing with different types of $\mathrm{MC}$ services that are used by SMEs of different size, are relatively rarely realized. However, when we take into account results for SME, without division by size, and when we compare them to results from similar research conducted in Lithuania, we can notice significant differencies when it comes to using MC services by SME. Lithuania has two and a half times larger GDP per capita than Serbia (Country Comparison, 2012). SME sector in Lithuania comprises almost 196.000 enterprises and employs 700.000 people (European Commission, 2011). Due to these reasons Lithuania is interesting for comparison.

By observing five MC services from the table below (Table 12), it is easy to notice significantly smaller volume of use of MC services in our SME than in Lithuania. Besides, decreasing order, observed by the type of service, is almost the same. That means that we are going through the same path when it comes to using Mc services, adding that we are lagging behind them.

Table 12. Comparison of the level of services MC use in Lithuania and Serbia

\begin{tabular}{|l|c|c|}
\hline \multicolumn{1}{|c|}{ Tipes of MC services } & Lithuania* & Our results \\
\hline Quality Management Sistems & $22 \%$ & $6,8 \%$ \\
\hline Information Systems & $21 \%$ & $5,8 \%$ \\
\hline Market Analysis (Market research) & $15 \%$ & $2,9 \%$ \\
\hline Computerised Manufact. Systems & $12 \%$ & $0 \%$ \\
\hline $\begin{array}{l}\text { Development Planning (Strategy and } \\
\text { business development) }\end{array}$ & $8 \%$ & $0,5 \%$ \\
\hline $\begin{array}{l}\text { *Adapted from: Urbonavichius, S., Dichius, V., (2005). Specifics of Business Consulting } \\
\text { Services Used by Small and Medium Enterprises in a Transition Economy. Engineering } \\
\text { Economics. No 3 (43).p.76. }\end{array}$ \\
\hline
\end{tabular}

Source: Author

That can be explained by earlier and more successfull passing through transition period (Lithuania has came out of SSSR in 1990, and is a member of EU since 2004), higher level of development of consulting support for SME, as well as higher level of development and financial strength of Lithuanian SME. It can also be observed from the other aspect - the more you use MC services, SMEs are more developed and achieve better results. 
Dukić D. et al.: Extent and types of management consulting services to SMEs in...

\section{Conclusions}

In general, growing enterprises use services of external professional consultants to relatively high extent for the current level of economic development of our country. The first tested hypothesis in this research assumes that the volume of MC services used increase with the age of SME (reference: Age of SME - Volume of using MC services). However, the results of conducted research have shown that the volume of used MC services is not dependent, that is, it does not depend on the age of the enterprise. Based on the said it can be concluded that the experience of the entrepreneur and the owners-managers, does not affect the determination of the critical engagement of external professional consultants.

The second hypothesis which was examined is that use of MC services increases along with the growth of enterprise (reference: Size of SME Volume of using MC services). In order to examine this hypothesis we questioned separately groups of micro, small and medium enterprises, and this research undoubtedly proves that with the growth of SME, use of MC services also rises.

The third hypothesis refers to types of MC services used by SME (reference: Size of SME - Types of MC services used). It can be derived from the results of this research regarding the type of $\mathrm{MC}$ service used by growing micro, small and medium-sized enterprises. However, micro enterprises, with 1-10 employees use MC services of general nature, such as start-up training, sales skills, state support and others. The importance of subsidizing the price of these services (they are often free) by different state and international institutions is apparent.

Along with the growth of an enterprise, in the case of small enterprises with 11-49 employees, start-up training losses its importance, while external professional consulting support in domain of the state support projects becomes more important. Also, specifically defined MC services, such as business planning, quality system, fair shows gain importance. This indicates the desire and need for a long-term business perspective, the increase of market share, better market positioning, development and differentiation of own products and services, learning from others, and reaching as much potential buyers in the county as possible.

The next researched level of size of the enterprises are medium-sized enterprises, in whose case apart from fair shows and quality systems, the biggest interest in $\mathrm{MC}$ services in the field of finances, accounting and taxes, information systems and technologies is visible. Therefore, apart from interest in market position and quality, business is expanded to foreign markets and better-sophisticated business approach shows the understanding of the 
Dukić D. et al.: Extent and types of management consulting services to SMEs in...

importance of detailed knowledge of financial-tax aspect of doing business, and uses of information systems and technologies.

Accordingly, from the aspect of enterprise size, the level of MC services use increase with enterprises growth. On this basis it can be concluded that the complexity of organization (enterprise), which is greater in case an enterprise is larger, and the complexity of business activities, have a decisive influence on the need for MC services. Usually, the larger the enterprise, the higher the incom, so the price of $\mathrm{MC}$ services in a relative sense is lower, more precisely, it is more bearable for larger than for smaller enterprises.

Implications of this research relate to all micro, small and medium enerprises. The results obtained point to entrepreneurs and SME owners, to key MC services they need for successfully growth and development.

In addition, these results are useful for institutional, as well as for private providers of MC services. Preferred types of MC services within each researched group of enterprises, can serve as a guide to providers of these services for acquiring and deepening of needed knowledge and skills.

It is also in connection with demand, and thus the need and the possibility to create and adapt the offer of MC services to target group of companies. Orientation data indicate that a medium-sized enterprise that uses nine times as many management consulting services than a micro enterprise enables providers of management consulting services to address that target group. On the other side, very low rate of MC services use by micro enterprises, shows the need to engage state institutions for support of SME sector, in the sector of micro and small businesses.

Of course, there is always the danger of corruption and similar quasicommercial activities. In that sense, a deeper study and better understanding of mechanisms, processes and laws of management consulting, increase the possibility of using its positive sides and contribute to the reduction of anomalies and negative effects.

\section{References}

Adižes, I. (1994). Životni ciklus preduzeća - kako i zašto preduzeća rastu i umiru i šta činiti u vezi sa tim. Novi Sad, Prometej.

Applebaum, S. H., \& Hinds, D. (1984). The Role of the Management Consultant in Small Business. Business Quarterly, 9(3), 43-51.

Birch, D. L. (1987). Job Creation in America: How Our Smallest Companies Put the Most People to Work. New York, Free Press/MacMillan Publishing Company.

Birch, D. L. (1981). Who Creates Jobs?, The Public Interest, New York, 65(Fall), 3-14.

Bower, M. (1982). The forces that launched management consulting are still at work, Journal of Management Consultancy, 1(1), 4-6. 
Dukić D. et al.: Extent and types of management consulting services to SMEs in...

Christensen, R. P., \& Klyver, K. (2006) Management consultancy in small firms: how does interaction work? Journal of Small Business and Enterprise Development, Vol. 13 (3),.299 - 313.

Crisman, J. J., \& McMullan, W. E. (2000). A Preliminary Assessment of Outsider Assistance as a Knowledge Resource: The Longer-Term Impact of New Venture Counseling, Entrepreneurship:Theory \& Practice, 24(3), 41-57.

Drucker, P. (2003). The New Realities. New Brunswick (U.S.A.) and London (U.K.), Transaction Publishers.

Dukić, D., \& Milivojević, T. (2011). Model menadžment konsaltinga za preduzetnike i vlasnike malih preduzeća, Industrija, Ekonomski institut Beograd, 39(2), 335354.

Dukić, D., \& Nikolić, I. (2010). Menadžment konsalting u sektoru MSSP iz perspektive klijenta, Management - časopis za teoriju i praksu menadžmenta, FON Beograd, 15(55), 69-77.

European Foundation for Entrepreneurship Research - EFER. (1996). Europe's 500. Dynamic Entrepreneurs The Job Creators. Brussels, Belgium, European Union.

Gattiker U. E., \& Larwood, L. (1985). Why do clients employ management consultants? Consultation, 4(2), 119-129.

Hagedorn, H. J. (1982). The anatomy of ideas behind a successful consulting firm. Journal of Management Consulting, 1(1), 49-59.

Jovanović P. (2005). Menadžment - teorija i praksa. Beograd, Fakultet organizacionih nauka.

Kubr, M. (2002). Management consulting: A guide to the profession (fourth edition). Geneva, International Labour Office.

McLarty, R. (2003). The Attitudes of British Managers in Small and Medium- Sized Enterprises to the Implementation of Value Chain Concept. International Journal of Management, 20(4), 430-442.

Mihajlović, B., Paraušić, V., \& Potrebić, V. (2006). Uloga konsaltinga u restrukturiranju preduzeća u tranziciji. Industrija, 34(3), 81-90.

National Agency for Regional Development. (2011). Report of SMEs - 2010. Belgrade, Serbia.

Mughan, T., Lioyd-Reason, L., \& Zimmermann, C. (2004). Management Consulting and International Business Support for SMEs: Need and Obstacles. Education + Training, 46(8-9), 424-432.

Naylor, J., Hawkins N., \& Wilson C. (2000). Benchmarking Marketing in an SME: The Case of an Italian Kitchen Furniture Manufacturer. The Marketing Review, 1(3), 325-339.

Rajkov M., Sajfert, Z. (1999) Preduzetnički menadžment. Beograd, Fakultet organizacionih nauka.

Stoner, J., \& Freeman, E. (1989). Management. New York, Prentice Hall, Englewood Cliffs.

Storey, D. J. (2004). Exploring the link, among small firms, between management training and firm performance: a comparison between the UK and OECD countries. The International Journal of Human Resource Management, 15(1), 112-130.

Urbonavichius, S., Dichius, V., (2005). Specifics of Business Consulting Services Used by Small and Medium Enterprises in a Transition Economy. Engineering Economics, 3(43), 74-81. 